mental result that each of these contributes approximately 50 per cent to the total emission of $\beta$-ray energy. The combined correction for these effects was 4.3 per cent. The $\gamma$-ray correction, based on the measured value of $12 \cdot 1 \mathrm{r} . / \mathrm{hr} . / \mathrm{mc}$. at $1 \mathrm{~cm}$., amounted to $8 \cdot 8$ per cent.

A measurement of the half-life was made on a $\beta$-ray ionization chamber, and a regression line through seven points, spread over $8 \mathrm{hr}$., gave a halflife of $2.259 \pm 0.003 \mathrm{hr}$. (after correcting for 0.7 per cent iodine-131 initially present as contaminant). This figure is subject to a systematic error not greater than about $0.005 \mathrm{hr}$. due to possible error in the chamber background.

We are grateful to Dr. G. B. Cook and Mr. J. D. Eakins, of the Isotopes Division, Atomic Energy Research Establishment, Harwell, for their co-operation and their advice on the separation of iodine-132, and to the Medical Research Council for the loan of the equipment used in the ionization measurements.

Department of Medicine,

E. W. EMERY

University of Manchester.

Physics Department,

Guy's Hospital Medical School. July 13.

1 Winsche, W. E., Stang, Jun., L. G., and Tucker, W. D., Nucleonics, 8, 14 (1951).

'Mayneord, W. V., and Sinclair, W. K., “Adv. Biol. and Med. Phys.”, 3, 1 (1953)

${ }^{3}$ Gray, L. H., Brit. Med. Bull., 8, 115 (1952).

- Perry, W. E., "Standardisation of Radioactive Isotopes" (National Physical Laboratory, 1953).

- Gray, L. H., Brit. J. Radiol., 22, 667 (1949).

- Novey, T. B., Sullivan, W. H., Coryell, C. D., Newton, A. S., Sleight, N. R., and Johnson, O., Plutonium Project Record, N NES 9,
Plo, Paper 135 .

\section{Successful Inter-breed Transfer of Ova in Sheep}

SUCCESSFUL transfer of ova by surgical techniques in sheep has been reported by Warwick and Berry ${ }^{1}$ and Lopyrin, Loginova and Karpov ${ }^{2}$. In our experiments, transfers of ova have been carried out between the Border Leicester (mature weight 140-180 lb.) and Welsh Mountain (mature weight 80-100 lb.) breeds in order to evaluate the maternal influence on the size of lambs at birth and at subsequent ages.

Thirty Welsh Mountain and twenty-five Border Leicester ewes were run with a raddled, vasectomized ram. Synchronization of the onset of cestrus in the majority of the ewes was attempted by means of progesterone treatment ${ }^{3}$. Four days before the expected onset of cestrus, the donors were treated with raw pregnant mare serum (stored at $-10^{\circ} \mathrm{C}$.) and then run with a fertile ram of the same breed. The recipients remained with the vasectomized ram.

Laparotomy in the donors was performed 68-90 hr. after the onset of cestrus. In vivo recovery of the ova from the Fallopian tubes was carried out as described by Chang4. Either homologous blood serum or Ringer's solution was used as the flushing medium. The ova were transferred in a glass pipette which was inserted into the lumen of the uterine horn near the utero-tubal junction. Single ova were transferred to seventeen recipients and one ewe received two ova. After recuperation, the recipients were run with a fertile ram of the opposite breed.

One male and two female Border Leicester lambs were born to Welsh ewes, all requiring assistance at parturition, and five Welsh ewe lambs were born to Border Leicester ewes. The mean birth-weight of the Border Leicester lambs from the Welsh ewes was $11 \cdot 1+0 \cdot 38 \mathrm{lb}$. after a mean gestation period of $146.0 \pm 0.58$ days, and that of the Welsh lambs from Border Leicester ewes was $9 \cdot 5+0 \cdot 18 \mathrm{lb}$. after a mean gestation period of $149 \cdot \overline{6} \pm 0.51$ days. Birth-weights and mean gestation periods of Border Leicesters are normally $13 \cdot 5-14 \mathrm{lb}$. and 145 days respectively, whereas the corresponding figures for the Welsh breed are 8-8.5 lb. and 147 days respectively.

Transfers were successful when cestrus in the recipients commenced from $16 \mathrm{hr}$. before to $20 \mathrm{hr}$. after that in the donors. Thirty-seven ova, representing 58 per cent of the ovulations, were recovered fron thirteen ewes; the standard error of the recovery. rate was 20.2 per cent. Of the eight successful transfers, two were 4-cell, five 8-cell and one a 16-cell ovum. Four out of seven and four out of eleven transfers, using blood serum and Ringer's solution respectively, were successful. Prior to transfer to the recipients, seven of the ova which developed to term were exposed for $30-45 \mathrm{~min}$. at room temperature, and one developed after exposure for $70 \mathrm{~min}$.

Our results to date indicate that the influence of the size of the breed of the mother on birth-weight is marked, and that ovum transfer in the sheep can be as successful as in the rabbit ${ }^{5}$.

School of Agriculture,

University of Cambridge.

\section{G. L. HunTer}

\section{E. Adams}

L. E. Rowson

Agricultural Research Council

Unit of Animal Reproduction, Cambridge.

Sept. 15.

1 Warwick, B. L., and Berry, R. O., J. Hered., 40, 297 (1949).

${ }^{2}$ Lopyrin, A. I., Loginova, N. V., and Karpov, P. L., Sovetsk Zooteh., 8, 50 (1950) (Anim. Breed. Abst., 18, 1449).

'Hunter, G. L., J. Endocrin., 10, viii (1954).

1 Chang, M. C., J. Exp. Zool., 121, 351 (1952).

${ }^{5}$ Chang, M. C., Nature, 161, 978 (1948). Dowling, D. F., J. Agric.

\section{Mechanical Separation of Plant Tissues}

An investigation was recently carried out in this Laboratory into the best way of separating the fibre strands of various 'bast' and 'leaf' fibres into their component elementary cells. The fibres were first treated by the chlorite method ${ }^{1}$ and then divided into two parts. One part was subjected to shalking with glass beads in a glass bottle, whereas the other part was shaken in a polythene bottle with short (about $2 \mathrm{~cm}$.) lengths of glass rod covered with rubber 'policemen'. Microscopical examination showed that excellent separation was effected by the second method without damage to the fibres, although damage was pronounced with the glass beads. It is possible that this method, which appears to be not generally known, may be capable of wider application for separating plant tissues.

Colonial Products Laboratory,

C. G. JARMAN

Imperial Institute Building,

South Kensington,

London, S.W.7. June 1.

1 Spearin, W. E., and Isenberg, I. H., Science, 105, 214 (1947). 